\title{
GENEZA I ROZWÓJ NIERÓWNOŚCI SPOŁECZNYCH W PARADYGMATACH BADAWCZYCH ARCHEOLOGII. ZARYS PROBLEMATYKI
}

\author{
THE EMERGENCE AND DEVELOPMENT OF SOCIAL INEQUALITY \\ IN ARCHAEOLOGICAL RESEARCH PARADIGMS. AN OUTLINE
}

\begin{abstract}
The article brings about an analysis of major conceptualizations of processes leading to the emergence and development of social complexity and inequality, which have been formulated within major paradigms of contemporary archaeology. The most significant contribution to these issues was offered by archaeologies inspired by functionalism and neoevolutionism. These attempts corresponded with an attempt to turn archaeology into a nomothetic discipline. Of different character were works inspired by Marxism, Neomarxism, and poststructuralism. They offered a valuable contribution to the conceptualization of the means of achieving social goals and performing social roles by different actors.
\end{abstract}

KEY WORDS: evolutionism, Marxism, Neomarxism, social complexity, hierarchy, chiefdom, early state

\section{WSTĘP}

Organizacja społeczna grup pradziejowych i wczesnohistorycznych $\mathrm{w}$ ich rozmaitych wymiarach, oraz zmiany zachodzące w czasie, były i pozostają przedmiotem zainteresowania przedstawicieli szeregu szkół badawczych w archeologii. W szczególnie czytelny sposób ta problematyka była podejmowana przez archeologię procesualnofunkcjonalistyczną, neoewolucjonistyczną, marksistowską i neomarksistowską oraz postprocesualną. Dyscypliny podejmujące się realizacji celów badawczych odnoszących się do zmiennych społecznych można zasadnie określać mianem archeologii społecznej. W bardzo ogólnym wymiarze jej cele można zdefiniować jako 'sposoby konceptualizacji stosunków między nami samymi a innymi, między społeczeństwem i historią w kontekście przeszłości i teraźniejszości' (Meskell 2006, 236). Z racji na cele stawiane $\mathrm{w}$ niniejszym artykule, jest ona rozumiana przede wszystkim jako archeologia bytu społecznego, który pozostaje rozpięty pomiędzy czasowością, przestrzennością i materialnością; inaczej: między czasem, przestrzenią i materią.

Jak podkreśla Alex W. Barker $(2008,513)$, niewiele problemów skupia w większym stopniu uwa- 
gę archeologów i antropologów zainteresowanych kwestiami społecznymi aniżeli początki i rozwój społecznej nierówności. Kent Flannery (1994, 101119) w swym wykładzie wygłoszonym w Londynie w 1992 roku na konferencji poświęconej stuleciu urodzin Gordona Childe'a, zwrócił uwagę, że pomiędzy dwiema ,historycznymi rewolucjami”: rewolucją neolityczną i rewolucją przemysłowa, miała miejsce trzecia, równie doniosła dla rozwoju społeczeństw pradziejowych. Doprowadziła ona do powstania społecznych nierówności, uformowania się elit, różnicowania pozycji społecznych oraz wykształcenia się ideologii i szeregu odmiennych postaw w obrębie wspólnot.

Celem artykułu jest analiza sposobów konceptualizacji 'bytu społecznego' w odniesieniu do początków, rozwoju i kształtowania się zróżnicowania i nierówności społecznych, które są formułowane przez najważniejsze nurty badawcze współczesnej archeologii. Z racji na obszerność i kompleksowość tej problematyki, pominięte zostaną kwestie metodologiczne związane z materialnymi pozostałościami tych procesów i archeologicznymi sposobami ich rozpoznania.

\section{PIERWSZE KONCEPTUALIZACJE}

Pierwszych prób konceptualizacji procesów społecznych w pradziejach należy upatrywać w ewolucjonizmie kulturowym końca XIX wieku. Ich autorem był L. H. Morgan, który w 1877 roku zaproponował wydzielenie trzech głównych epok w dziejach ludzkości: (i) dzikości, (ii) barbarzyństwa i (iii) cywilizacji (np. Daszkiewicz 2015). Pozwoliło to na dokonanie podziału grup ludzkich ze względu na ich poziom rozwoju na społeczeństwa prymitywne (pierwotne) i rozwinięte. Podstawą związków między ludźmi w społeczeństwach prymitywnych jest pokrewieństwo, podczas gdy fundamentem podziałów grupowych i hierarchii w społeczeństwach rozwiniętych są zależności i relacje o charakterze ekonomicznym, organizacyjnym (politycznym), militarnym i religijnym. Przynależność ludzi do poszczególnych grup ma tutaj podstawy instytucjonalne i prawne, i nie jest związane ze stopniem pokrewieństwa pomiędzy jednostkami. Przejście od stanu organizacji społecznej opartej na dominacji związków pokrewieństwa do form charakteryzujących się przewagą zależności instytucjonalnych było długotrwałym procesem, w trakcie którego obydwie formy organizacji społecznej ze sobą współwystępowały. Owo dziedzictwo ewolucjonizmu w znaczący sposób zaważyło na sposobach konceptualizacji zjawisk społecznych w archeologii, w tym także rozumienia procesów genezy i rozwoju nierówności społecznych. Co więcej, ewolucjonizm, obok marksizmu, stał się jednym $\mathrm{z}$ najważniejszych źródeł inspiracji dla badań archeologicznych podejmujących problematykę zjawisk społecznych w odległej przeszłości.

\section{ARCHEOLOGIE PROCESUALNE I NEOEWOLUCYJNE}

Pogłębiona konceptualizacja zmian społecznych, w tym rozpoznanie procesów różnicowania się społeczności ludzkich i powstawania nierówności społecznych, dokonała się za sprawą inspiracji funkcjonalistycznych i neoewolucyjnych w archeologii w latach 60. XX wieku. W pierwotnej wersji Nowej Archeologii połączono funkcjonalistycznie rozumienie człowieka z obecnym w tamtym czasie myśleniem systemowym i przyjęto istnienie odrębnych i wyraźnie wyodrębnionych obszarów jego życia. Struktura i organizacja społeczna otrzymała status jednego z podsystemów. Przyjmowano, że zmiany $\mathrm{w}$ jej charakterze, podobnie jak każdego $\mathrm{z}$ pozostałych podsystemów, były spowodowane czynnikami zewnętrznymi lub też wynikały z konieczności dostosowania się organizacji społecznej do zmian w pozostałych podsystemach, zgodnie z zasadą dążenia do stanu równowagi, którą miał cechować się każdy system. Zakładano pasywność grup i jednostek, które pozostawały zdeterminowane przez czynniki zewnętrzne. Skupiano się na procesach długiego trwania zachodzących w wielkiej skali, przyjmując jednocześnie unlinearność zmiany i postępu ujętej w postać meta-narracji (Binford 1962; 1965). Przyjęcie takich uproszczonych i mechanistycznych zasad nie stwarzało warunków do dokonania kompleksowej konceptualizacji mechanizmów zachodzących zmian społecznych. 
Możliwości takie zostały dopiero stworzone za sprawą wprowadzenia idei procesu kulturowego do agendy Nowej Archeologii. Mogła być ona już wówczas nazywana archeologią procesualną. Przeniesienie punktu ciężkości z adaptacji na proces stworzyło warunki konceptualizacji dynamiki rozwoju różnych aspektów przeszłych społeczności oraz umożliwiło odejście od ahistoryczności i synchronizmu ujęcia systemowego. Proces ujmowano teraz w perspektywie długiego trwania, dążąc do formułowania prawidłowości i generalizacji badanych zjawisk. Podstawowym kryterium klasyfikacji grup ludzkich w archeologii procesualnej był stopień ich zróżnicowania. Za najważniejsze mechanizmy odpowiedzialne za wykształcanie się zróżnicowania społecznego uznawano: (i) sukcesywne różnicowanie się, (ii) kumulatywny charakter zmiany społecznej oraz (iii) instytucjonalizację kompleksowości społecznej, w szczególności w zakresie administracji, handlu dalekosiężnego, pisma, a w późniejszym okresie także organizacji państwowej (Rowlands 1989, 32).

Największe zasługi dla badań nad zróżnicowaniem społecznym grup ludzkich, w tym powstania i rozwoju nierówności społecznych, wniosły inspiracje neoewolucjonistyczne wprowadzone do programu badawczego archeologii procesualnej. Nastapiło to pod koniec lat 70. XX wieku jako przejaw dążeń do nomotetyzacji dyscypliny. Dwoma najważniejszymi propagatorami neoewolucjonizmu byli Leslie White oraz Julian Steward, którzy bezpośrednio odwoływali się do XIX-wiecznej spuścizny ewolucjonizmu Morgana czy Tylora (Trigger 2006, 387). Idee te zostały następnie rozwinięte przez Marshalla Sahlinsa (e.g. 1975) i Elmana Service'a (e.g. 1970). Neoewolucjonizm doprowadził do wyróżnienia stadiów rozwoju ze względu na explicite zdefiniowane zmienne społeczne oraz stopień natężenia zróżnicowania i nierówności społecznych. Do najważniejszych czynników odpowiedzialnych za rozwój zróżnicowania społecznego w neoewolucjonizmie zalicza się: (i) wzrost populacji, (ii) agregację grup ludzkich, (iii) integrację społeczna, (iv) organizację i zarządzanie pracą, (v) pojawienie się specjalizacji, (vi) wymianę, (vii) konflikt zbrojny, (viii) intensyfikację zajęć rolniczych oraz (ix) nadwyżki w produkcji (Upham 1987, 348).

Podobnie jak miało to wcześniej miejsce w Nowej Archeologii, odwoływano się do unilinearnego modelu rozwoju społeczeństw, a ewolucję zjawisk kulturowych rozumiano normatywnie, zgodnie z po- stulatami Leslie White'a (O’Brien 1996, 1). Stopniowe różnicowanie się grup ludzkich ujmowano w schemat ewolucyjny zakładający pojawianie się następujących po sobie normatywnie rozumianych grup zwanych (i) gromadami, (ii) plemionami (społecznościami rozczłonowanymi), (iii) społecznościami wodzowskimi i (iv) wczesnymi państwami. W kolejnych latach zmodyfikowano ów schemat, wydzielając trzy kategorie: (i) społeczności egalitarne, (ii) społeczności wodzowskie oraz (iii) społeczeństwa wczesnopaństwowe (e.g. Peebles, Kus 1977, 427) oraz odrzucono linearny charakter rozwoju społeczeństwa pradziejowego. Przyjmowano jednak nadal, że wszystkie społeczeństwa przeszły przez kolejne fazy rozwoju organizacji społecznej. Zakładano jednocześnie, że grupa społeczna jest zwartą i homogeniczna jednostką, a jej członkowie dzielą powszechnie akceptowane zasady, normy i wartości.

Najwcześniejszą formą organizacji społecznej będącej efektem sformalizowanego zróżnicowania społecznego były społeczności wodzowskie. Cechuje je szereg cech, takich jak: (i) struktura hierarchiczna uwidaczniająca różnice w statusie społecznym pomiędzy ludźmi, (ii) podział na lineaże, które są klasyfikowane i porządkowane ze względu na skalę prestiżu i pochodzenia rodowego, (iii) prestiż i ranga określane na podstawie bliskości pokrewieństwa wobec wodza, (iv) dominująca pozycja wodza/przywódcy w relacjach społecznych, (v) lokalna specjalizacja produkcji rzemieślniczej, oraz (vi) obecność stałego ośrodka ceremonialnego i obrzędowego (Peebles, Kus 1977). Na rolę prestiżu w tworzeniu się i podtrzymywaniu systemu wodzowskiego zwracał szczególną uwagę Sahlins (1958). Zdaniem tego wybitnego badacza, pozycja wodza tworzy się dzięki otrzymywanym darom od pozostałych członków wspólnoty, co prowadzi do wzrostu jego prestiżu w grupie. Redystrybucja zgromadzonych w taki sposób dóbr nie ma zatem podstaw ekonomicznych i politycznych.

Bardziej zaawansowaną formą organizacji społecznej opartej na nierównościach społecznych są wczesne państwa. Charakteryzuje je szereg cech, takich jak: (i) oficjalna moc stanowienia praw i możliwość ich egzekwowania przez władcę, (ii) organizacja społeczeństwa w oparciu o klasy, a nie pokrewieństwo, (iii) oddzielenie funkcji zarządzających od funkcji kapłańskich, co oznacza oddzielenie pałacu od świątyni, (iv) terytorium państwa pozostające własnością rodu panującego, 
(v) obowiązek płacenia podatków i danin przez mieszkańców, oraz (vi) obecność zbiurokratyzowanej administracji w ośrodku centralnym, której podstawowym obowiązkiem jest ściaganie powinności oraz ich redystrybucja pomiędzy administrację, armię i rzemieślników (Peebles, Kus 1977).

W obrębie wczesnego państwa, H.J.M. Claessen i P. Skalnik $(1978,640$ n.) wyróżnili trzy fazy rozwojowe: (i) początkową, (ii) typową oraz (iii) przejściową. Pierwszą fazę charakteryzuje obecność indywidualnej własność ziemi i bydła, podczas gdy w przewadze pozostają kolektywne formy własności i użytkowania. Handel i wymiana pełnią bardzo ograniczoną rolę. Podatki mają z kolei formę dobrowolnych darów bądź okazyjnych świadczeń. Oficjalne funkcje i stanowiska są dziedziczne i wynagradzane zazwyczaj w postaci dóbr rzeczowych. Prawo i system kar pozostaja nieskodyfikowane, nie istnieje także odrębna grupa sędziów. W drugiej fazie rozwojowej wczesnego państwa prywatna własność ziemi i bydła jest nadal utrzymywana, ale znaczenie własności państwowej znacząco wzrasta. Handel i wymiana stają się wyraźnie rozwinięte, a ich wpływ na gospodarkę wykracza poza poziom lokalny. Wykształca się trwały system trybutów i podatków - płatnych bądź w dobrach rzeczowych, bądź w formie pracy i usług. Dziedziczenie stanowisk państwowych zaczyna być wyraźnie czytelne, ale pozostaje równoważone przez prawo władcy do mianowana osób pełniących funkcje, którzy są wynagradzani zarówno w dobrach naturalnych, jak i pieniężnych. Dochodzi także do pierwszych prób kodyfikacji prawa i systemu kar. W ostatniej fazie rozwojowej wczesnego państwa indywidualna własność ziemi i bydła staje się wyznacznikiem pozycji społecznej. Znacząco wzrasta gospodarcza rola handlu i wymiany, dochodzi do rozwoju systemu podatkowego oraz dalsza kodyfikacja prawa. Przyjmuje się, że wczesne państwa powstały $\mathrm{w}$ efekcie szeregu skomplikowanych procesów, do których należą: (i) przyjęcie i zaadoptowanie gotowych wzorców od społeczności o podobnej formie organizacji, (ii) napięcie między grupami ludzkimi a środowiskiem, które zamieszkiwały, (iii) zagrożenie zewnętrzne, (iv) stosowanie przemocy, (v) umowa społeczna oraz znacznie rzadziej (vi) długotrwałe procesy wewnętrzne (Tymowski 2012).

Aplikacja założeń neoewolucjonistycznych doprowadziła do zainteresowania się początkami i rozwojem takich zjawisk, jak: przemoc, domi- nacja, opór czy konflikt zbrojny oraz ich wpływu na procesy prowadzące do powstania nierówności społecznych. Władzę zdefiniowano jako 'umiejętność sprawowania kontroli nad innymi' (Renfrew 1984, 240), a więc przypisano ją osobom, które posiadają moc sprawczą. Za przejaw władzy uznano obecność uporządkowanej struktury organizacyjnej, wykorzystywanie symboli jako 'instrumentów dominacji' oraz jej przestrzenny wymiar (Renfrew 1984, 24-25). Dowiedziono, że formy organizacji szeregu podmiotów społecznych opartych na przemocy sięgają epoki żelaza, co pozwoliło na zakwestionowanie opinii Maxa Webera (2002, 1023), który utrzymywał, że państwo było pierwszą formą organizacji społecznej, która opierała się na przemocy i że 'przemoc nie jest naturalnie w żadnym razie normalnym czy jedynym środkiem państwa, z pewnością jednak swoistym dla niego'. Podobnego zdania był Hegel (1990, 528), który uważał, że wykształcenie się nierówności (społecznej) miało miejsce wraz z powstaniem państwa.

Wymianę i redystrybucję uznano za jeden z najważniejszych czynników prowadzących do powstania społeczności o znaczących różnicach społecznych. Wprowadzono rozróżnienie pomiędzy: (i) recyprokalnością, (ii) redystrybucją a (iii) wymianą rynkową (Polanyi 1975). Szczególną rangę przypisywano zapotrzebowaniu na egzotyczne produkty, które było dyktowane potrzebami elit. Przedmioty prestiżowe służyły elitom w podtrzymywaniu i wzmacnianiu ich pozycji społecznych. W tym kontekście pojawienie się kompleksowości społecznej należy wiązać z konsumpcją dóbr prestiżowych.

Specjalizację zajęć gospodarczych i pojawienie się rzemiosła wiązano zazwyczaj $\mathrm{z}$ intensyfikacją zajęć rolniczych. Jej pojawienie się uważano za niezbędny warunek powstania elit, które nie musiały być już wówczas bezpośrednio zaangażowane w zajęcia o charakterze produkcyjnym. Specjalizacja i wymiana pozostawały w skomplikowanych relacjach z procesami prowadzącymi do powstania i rozwoju nierówności społecznych. Zdaniem Brumfield and Earle (1987) można wyróżnić trzy różne formy specjalizacji: (i) komercyjną, (ii) adaptacjonistyczną oraz (iii) polityczną. W pierwszym modelu przyjmuje się, że intensyfikacja specjalizacji i wymiany jest integralnie związana ze spontanicznym wzrostem gospodarczym. Doprowadza w niejako automatyczny sposób do wzrostu zróżnicowania społecznego. Model apatacjonistyczny za- 
kłada aktywną rolę liderów w inicjowaniu i wspieraniu wymiany jako części gospodarki opartej na dystrybucji. Model polityczny z kolei zakłada in- tencjonalne działania liderów wspierających i podtrzymujących specjalizację i wymianę, której stają się najważniejszymi beneficjentami.

\section{ARCHEOLOGIE MARKSISTOWSKIE I POSTPROCESUALNE}

Archeologia postprocesualna, zrodzona z krytyki procesualizmu, ma wyraźnie charakter archeologii społecznej (Meskell 2006). Obejmuje ona szerokie spektrum podejść badawczych o rozmaitej proweniencji. Na najbardziej ogólnym poziomie można uznać, że zakładają one wewnętrzną przyczynowość zmiany. Znaczącym wkładem do konceptualizacji procesów genezy i rozwoju nierówności społecznych było wprowadzenie kategorii sprawstwa (agency). Umożliwia ono wyjście poza ograniczenia dychotomicznego podziału na jednostkę i społeczeństwo, postrzeganych jako dwie przeciwstawne kategorie społeczne. Przyjmuje się, że działanie społeczne podejmowane przez podmioty wyposażane w owo sprawstwo doprowadza do tworzenia i zmian struktury społecznej (Giddens 2003). Proces ten ma miejsce w ramach wyznaczanych przez struktury, co sprawia, że owe działania nie pozostają do końca uświadamiane przez podmioty społeczne oraz posiadają zarówno uświadamiane, jak i nieuświadamiane konsekwencje. Ważną rolę w tym procesie posiadają rzeczy, które wraz z umiejętnościami określane są przez Giddensa (1997) mianem zasobów alokacyjnych i autorytatywnych. Te pierwsze odnoszą się do możliwości sprawowania kontroli nad obiektami i dobrami materialnymi, takich jak elementy środowiska, a także możliwości wytwarzania dóbr (technologia) oraz powstałych w ich efekcie przedmiotów. Odnoszą się także do możliwości dostępu, zdobycia i wykorzystania owych dóbr. Zasoby autorytatywne z kolei oznaczaja moc sprawowania kontroli nad działającymi podmiotami, co w rezultacie pozwala na samoorganizowanie się grup. W ten sposób stają się narzędziami dominacji, gdyż umożliwiają gromadzenie materialnych i organizacyjnych form ułatwiających działanie. Ich aktywne wykorzystywanie przez grupę dokonuje się w warunkach określonych przez reguły semantyczne. Działanie to przyjmuje postać uogólnionego i dyskursywnego, aczkolwiek nie wypowiadanego, doświadczenia i prowadzi do tworzenia i reprodukcji praktyk społecznych. Proces ten jest określany mianem mobilizacji owych zasobów.
Dużo ważniejsze znaczenie dla interesującej nas problematyki ma tradycja neomarksistowska. Dzięki inspiracji myślą Louisa Althusserla, odrzucono stwierdzenie o ekonomicznym zdeterminowaniu ideologii i jej funkcjonalnej zależności od bazy. Zamiast tego uznano, że celem ideologii jest maskowanie sprzeczności i konfliktów w obrębie sił i stosunków społecznych, neutralizowanie niesprawiedliwości czy wreszcie fałszowanie rzeczywistości. Oznacza to, że przeciwstawne interesy rozmaitych podmiotów społecznych pozostają zazwyczaj ukryte za sprawą jej maskującej roli. Ideologia staje się więc narzuconym obrazem rzeczywistości. W takim rozumieniu ukryte pozostają także nierówności społeczne. W tej sytuacji konieczne stało się wprowadzenie wyraźnego rozróżnienia na faktyczną rolę podmiotów społecznych oraz sposoby ich przedstawienia w praktyce społecznej. Wskazuje się na niebezpieczeństwo automatycznego ujmowania kultury materialnej jako bezpośredniego odbicia faktycznych ról społecznych jednostek czy grup, które ją wytworzyły. Należy także pamiętać, że same strategie przedstawiania stają się formą władzy (Hodder 1991, 13).

Neomarksizm wprowadził także pojęcie władzy do czegoś (will to power), rozumianej jako wolność działania w świecie (uprzedmiotowienie, manipulowanie, maskowanie, aktywność) w przeciwieństwie do procesualnej definicji władzy odnoszącej się do kontroli i dominacji nad kimś lub nad czymś. Po odrzuceniu klasowego charakteru społeczności pradziejowych, główna oś konfliktu miała przebiegać pomiędzy grupami definiowanymi ze względu na płeć (kobiety vs. mężczyźni), wiek (starzy vs. młodzi) oraz więzy pokrewieństwa. Grupy te nie są w żadnej mierze rozumiane w sposób normatywny. Zwrócono także uwagę na partykularność warunków, w których powstaje i kształtuje się podmiotowość określonej jednostki społecznej, która pozostaje w stanie ciągłej transformacji i przekształcania się. Należy je zatem postrzegać 'kontekstualnie', zdecydowanie odchodząc od wydzielania jakichkolwiek abstrakcyjnych stadiów rozwoju w ewolucji społecznej. 
Nieco odmienne stanowisko zostało wypracowane $\mathrm{w}$ środowisku archeologów inspirowanych neomarksizmem francuskim, tzw. marksizmem strukturalnym (np. Frankenstein, Rowlands 1978; Gilman 1981). W rozumieniu tej szkoły badawczej, główna oś konfliktu przebiega pomiędzy interesami grupy społecznej a siłami i stosunkami produkcji. Przyjmuje ona postać struktury, która odnosi się do relacji produkcji i zawłaszczania, które z kolei pozostają ukryte za relacjami społecznymi pomiędzy różnymi podmiotami społecznymi (Hodder, Hutson 2003, 76). Inspirowani tymi ideami Frankenstein i Rowlands (1978), podjęli próbę wyjaśnienia mechanizmu rozwarstwienia społecznego w europejskiej epoce żelaza. Konstytutywną rolę w tym procesie przypisali dobrom prestiżowym z basenu Morza Śródziemnego, które były pozyskiwane przez wykształcające się elity z Europy Środkowej. Proces ten doprowadził do zdobycia całkowitej kontroli nad tą wymiana, a pozyskanymi dobrami obdzieleni zostali jedynie najbardziej zaufani stronnicy owych elit.

Oryginalną konceptualizację procesów prowadzących do powstania zróżnicowania i nierówności społecznych, nazywaną modelem dynamicznego procesu polisemantyzacji kultury, zaproponował Stanisław Piekarczyk (1972; 1976). Odwołuje się w niej do komunikacji wewnątrzkulturowej, która jest generowana przez splot elementów związanych z czynnikami łączącymi tę grupę, zapewniającymi jej kulturową wspólnotę. Grupy o kulturze monosemantycznej charakteryzują się tym, że 'wszyscy członkowie grupy dysponuja teoriomnogościową sumą zinterioryzowanych informacji, przekazywanych w postaci dostępnych wszystkim komunikatów'. Z kolei społeczności o kulturze polisemantycznej charakteryzują się 'systemem złożonym co najmniej z dwóch podgrup o różnym systemie społecznym, mających dostęp do teoriomnogościowej sumy informacji', a informacje, które 'artykułują i programują zachowanie członków danych podgrup w taki sposób, że niektóre standardy zachowania są dla wszystkich podgrup wspólne, pozostałe zaś odmienne'. Model Piekarczyka pozwala na uchwycenie stopniowej polisemantyzacji kultury grup ludzkich i przejścia od grup o strukturze egalitarnej i kulturze monotematycznej do bardziej skomplikowanych form organizacji opartych na hierarchii, które cechują się kulturą polisemantyczną.

\section{UWAGI KOŃCOWE}

Przedstawiony ogólny zarys najważniejszych form konceptualizacji procesów doprowadzających do powstania i instytucjonalizacji nierówności społecznych w archeologii pozwala na sformułowanie kilku spostrzeżeń. Nie ulega wątpliwości, że najbardziej spójne propozycje w zakresie studiów nad tymi zjawiskami zostały zaproponowane $\mathrm{w}$ archeologiach inspirowanych ideami funkcjonalistycznymi i neoewolucjonistycznymi. Wynika to zapewne z wyraźnie społecznego charakteru zainteresowań obydwu szkół badawczych, szczególnie tej ostatniej, a także postulowanej skali tych zjawisk, w szczególności zaś procesów długiego trwania. Paradoksalnie, biorac pod uwagę bezpośrednie odwoływanie się do społecznego wymiaru funkcjonowania grup ludzkich, poznawczo mniej wartościowe są propozycje archeologii interpretacyjnych, włączając $\mathrm{w}$ to prace inspirowane marksizmem, neomarksizmem i poststrukturalizmem. Odnoszą się one w większym zakresie do konceptualizacji różnych aspektów procesów społecznych, w tym realizacji celów społecznych i odgrywania ról społecznych przez rozmaite podmioty, niż do prób ustalenia długofalowych konsekwencji tych działań. Marginalne znaczenie dla zrozumienia procesów kształtowania i rozwoju nierówności społecznych posiadaja paradygmaty badawcze odwołujące się do kultury jako podstawowej zmiennej opisującej grupy pradziejowe i wczesnohistoryczne. 


\section{BIBLIOGRAFIA}

Barker A.W. 2008. Chiefdoms. (W:) C. Chippendale, A. Bentley and H. Maschner (eds.), A Handbook of Archaeological Theory. Walnut Creek, 515-532.

Binford L.R. 1962. Archeology as anthropology. American Antiquity 28, 217-225.

Binford L.R. 1965. Archaeological systemics and the study of culture process. American Antiquity 31, 203-210.

Brumfield E.M., Earle T.K. 1987. Specialization, exchange, and complex societies. (W:) E.M. Brumfield and T.K. Earle (eds.), Specialization, Exchange, and Social Complexity. Cambridge, 1-9.

Claessen H.J.M., Skalník P. (eds.). 1978. The Study of the State. Mouton.

Daszkiewicz W. 2015. Ewolucjonistyczna teoria kultury w antropologii społecznej. Zeszyty Naukowe KUL 59 (4), 149-164.

Flannnery K. 1994. Childe the evolutionist. A perspective from Nuclear America. (W:) D.R. Harris (ed.), The Archaeology of V. Gordon Childe. Chicago, 101-119.

Frankenstein S., Rowlands M. 1978. The internal structure and regional context of early Iron Age society in south-western Germany. Bulletin of the Institute for Archaeology 15, 73-112.

Giddens A. 1997. Sociology. The third edition. London.

Giddens A. 2003. Stanowienie społeczeństwa. Zarys teorii strukturacji. Poznań.

Gilman A. 1981. The development of social stratification in Bronze Age Europe. Current Anthropology 22(1), 1-7.

Hegel G.W.F. 1990. Encyklopedia nauk filozoficznych. Warszawa.

Hodder I. 1991. Interpretative archaeology and its role. American Antiquity 56, 7-18.

Hodder I., Hutson S. 2003. Reading the Past. Current Approaches to Interpretation in Archaeology. Cambridge.

Meskell L. 2006. Social archaeology. (W:) C. Renfrew, P. Bahn (eds.), Archaeology: the Key Concepts. London, 235-240.
O’Brien M.J. 1996. Evolutionary archaeology. An introduction. (W:) M.J. O’Brien (ed.), Evolutionary Archaeology: Theory and Application. Salt Lake City, 1-22.

Peebles C.S., Kus S.M. 1977. Some archaeological correlates of ranked societies. American Antiquity 42, 421448.

Piekarczyk S. 1972. Historia, kultura, poznanie. Ksiażka propozycji. Warszawa.

Piekarczyk S. 1976. Rozważania o poznaniu historycznym. Fakty, metody, źródła, teorie. Studia Źródłoznawcze 20, 141-162.

Polanyi K. 1975. The Great Transformation. The Political and Economic Origins of our Time. London.

Renfrew C. 1984. Approaches to Social Archaeology. Edinburgh.

Rowlands M. 1989. A question of complexity. (W:) D. Miller, M. Rowlands (eds), Domination and Resistance. London, 29-40.

Service E. R. 1970. Cultural Evolutionism: Theory in Practice. Toronto.

Sahlins M.D. 1958. Social Stratification in Polynesia. Seattle.

Sahlins M.D. 1975. Ewolucja: konkretna i ogólna. (W:) W. Derczyński, A. Jasińska-Kania, J. Szacki (red.), Elementy teorii socjologicznych. Materiaty do dziejów współczesnej socjologii zachodniej. Warszawa, 350-373.

Trigger B. 2006. A History of Archaeological Thought. 2nd editon. Cambridge.

Tymowski M. 2012. Organizacja społeczeństwa. (W:) S. Tabaczyński, A. Marciniak, D. Cyngot, A. Zalewska (red.), Przeszłość społeczna. Próba konceptualizacji. Poznań, 770-782.

Upham S. 1987. A theoretical consideration of middle range societies. (W:) R.D. Drennan, C.A. Uribe (eds.), Chiefdoms in the Americas. New York, 417-453.

Weber M. 2002. Gospodarka i społeczeństwo. Zarys socjologii rozumiejacej. Warszawa.

\section{THE EMERGENCE AND DEVELOPMENT OF SOCIAL INEQUALITY IN ARCHAEOLOGICAL RESEARCH PARADIGMS. AN OUTLINE}

\section{SUMMARY}

The article brings about an analysis of the means of conceptualizing the beginnings and developments of social complexity and inequality by major schools of archaeological thought. The first attempts of grasping the nature of social processes in the past are attributed to cultural evolutionism from the second half of the $19^{\text {th }}$ century. L. H. Morgan (1877) distinguished three major stages in the development of humankind (i) savagery, (ii) barbarism, 
and (iii) civilization. The legacy of evolutionism is discernible in dominant modes of studying social issues in archaeology, including the emergence and development of social differentiation and inequality.

Studies of social organization of prehistoric and early historic communities were particularly developed in functional-processual, neoevolutionary, Marxist, Neomarxist and post-processual archaeologies. The New Archaeology of the 1960s linked the functionalist approach with system theory. A human system was believed to be composed of distinct and clearly distinguished sub-systems. Social organization was defined as one of such sub-systems. A more comprehensive understanding of mechanisms of social change, marking a departure from largely ahistorical and synchronic character of the systemic approach, was only possible after introducing the idea of cultural process. It made it possible to re-name this paradigm into processual archaeology.

The most significant contribution to studies of social complexity, including the emergence and development of social inequality, was made by neoevolutionary ideas in processual archaeology from the end of the 1970s. The increasing differentiation of human groups was defined in the form of evolutionary scheme assuming a subsequent emergence of normatively understood groupings such as (i) bands, (ii) tribes, (iii) chiefdoms, and (iv) early states. Among the most important factors responsible for the development of social differentiation in neoevolutionism were (i) population increase, (ii) aggregation of human groups, (iii) social integration, (iv) organization management of labor, (v) emergence of specialization, (vi) exchange, (vii) military conflict, (viii) intensification of farming, and (ix) surplus product.

A significant contribution to studies of the emergence and development of social inequality in post-processual archaeology was introduction of a category of agency. In a different vein, Neomarxist archaeology of the Alhusserlian tradition argued that the main role of ideology is to disguise contradictions and conflicts between base and superstructure, neutralize the injustice, and falsify the reality. A different approach was developed by archaeologists inspired by French Marxism, the so-called structuralist Marxism. It was argued that the major conflict exists between interest of social group and its mode and relations of production. It has a form of structure pertaining to the relation between production and appropriation, which themselves remain hidden behind social relations between different social groupings.

Adresy Autorów:

Prof. dr hab. Arkadiusz Marciniak

Instytut Archeologii UAM

Collegium Historicum

ul. Umultowska 89D

61-614 Poznań

e-mail: arekmar@amu.edu.pl

Prof. dr hab. Stanisław Tabaczyński

Instytut Archeologii i Etnologii PAN

\author{
Al. Solidarności 105 \\ 00-140 Warszawa \\ e:mail: stantab@iaepan.edu.pl
}

